\title{
An empirical study of e-government diffusion in Fiji: a holistic and integrative approach
}

\author{
Fang Zhao ${ }^{\mathrm{a}}$, Suwastika Naidu ${ }^{\mathrm{b}}$, Gurmeet Singh ${ }^{\mathrm{b}}$, Aarti Sewak ${ }^{\mathrm{b}}$, Anand Chand \\ and Maureen Karan ${ }^{b}$
}

${ }^{a}$ School of Business and Law, Edith Cowan University, Joondalup, Australia; ${ }^{\text {b}}$ Faculty of Business and Economics, The University of the South Pacific, Suva, Fiji

\begin{abstract}
Pacific Island countries (PICs) are facing certain unique challenges in e-government diffusion due to their geographic, cultural, social, and economic environments. However, very few rigorous empirical studies have been published about e-government diffusion issues in the region. To address the knowledge gap, we conducted a case study of Fiji. Drawing on Fountain's technology enactment framework as a theoretical lens, we identified and investigated in a holistic and integrative way the major issues and challenges which influenced e-government diffusion and outcomes in Fiji. The study has significant implications both for research and practices not only in Fiji but also in the PICs.
\end{abstract}

KEYWORDS E-government; diffusion; Fiji

\section{Introduction}

The world continues to become increasingly digitalized, creating opportunities for improved services to the community while, at the same time, putting pressure on governments to make national digital infrastructure more efficient and effective in delivering these services to citizens and businesses. E-government has become an important part of improving these services to the community. It was recently estimated that government digitalization could generate over $\$ 1$ trillion each year worldwide (Corydon, Ganesan, and Lundqvist 2016). In this regard, e-government has significant political, social, and economic implications.

E-government is defined as the use of information technology to improve the business processes and service delivery of government departments and other government entities (World Bank 2008). For the purposes of this paper, we use the term 'e-government diffusion' to refer to e-government development and citizens' adoption of e-government.

Pacific Island countries (PICs) are a group of small island developing states located in the Pacific Ocean that share similar geographic, demographic, cultural, economic, and political environments and development problems. Eighty-nine per cent of the indigenous populations in the region share Melanesian culture. Most PICs are archipelagos of isolated islands in tropical regions with limited resources and a 
high level of vulnerability to natural hazards. The economies of PICs are limited by their small domestic markets, geographic isolation and dispersion, and dependence on foreign donation and investment. As a result, the costs of providing basic services and infrastructure including telecommunications are very high. The study by Cullen and Hassall (2017) found that governance structure in PICs is changing from chiefly authority derived from traditional rural and village living to urbanized, mostly elected authorities at town, provincial, and national levels. These contexts pose unique challenges and issues to e-government diffusion in the region. Compared with many parts of the world, e-government development among PICs is relatively low, according to UN e-government survey (United Nations 2016) (see Table 1 for world rankings).

However, after conducting an extensive search of the current literature, we found that the extant world e-government literature has not given sufficient attention to the PICs. This conclusion is supported by a newly published research book on e-government in PICs (Cullen and Hassall 2017) which attempts to address the gap. To develop an in-depth understanding of e-government diffusion in the PICs, we conducted a case study of Fiji. Our primary research question is what are the major issues and challenges facing e-government diffusion in Fiji?

The choice of Fiji was based mainly on three reasons: its economic performance, e-government development status, and the location of the researchers of this study when the primary data were collected. First, Fiji is one of the largest and most developed economies of the PICs with a GDP per capita of US $\$ 4200$ (IMF 2013). Second, Fiji leads arguably in e-government development in the PICs. According to the 2016 United Nations (UN) e-government survey (United Nations 2016), Fiji was ranked 96th in terms of e-government development index (EGDI) in the world. However, Fiji takes the lead in the PICs and is ranked number one. Table 1 provides a glimpse of e-government development performance among the PICs in the latest UN survey. Therefore, the selection of Fiji for this study was expected to generate wider research implications and to offer practical insights and value for the policy-makers not only in Fiji but also in other PICs. Third, all members of the research team were based in Fiji when the study was conducted. Most of the team members were Fijian locals who possessed an in-depth understanding of the environments that could affect e-government diffusion.

Table 1. Ranking of PICs for e-government development index (EGDI).

\begin{tabular}{lcccc}
\hline $\begin{array}{l}\text { Rank } \\
(\text { world })\end{array}$ & $\begin{array}{c}\text { Rank } \\
(\mathrm{PICs})\end{array}$ & \multicolumn{1}{c}{ Country } & EGDI & EGDI level \\
\hline 96 & 1 & Fiji & 0.4989 & Medium \\
105 & 2 & Tonga & 0.4700 & Medium \\
111 & 3 & Palau & 0.4546 & Medium \\
121 & 4 & Samoa & 0.4019 & Medium \\
145 & 5 & Kiribati & 0.3122 & Medium \\
146 & 6 & Micronesia (Federated States of) & 0.3103 & Medium \\
149 & 7 & Vanuatu & 0.3078 & Medium \\
151 & 8 & Tuvalu & 0.2950 & Medium \\
152 & 9 & Nauru & 0.2868 & Medium \\
156 & 10 & Marshall Islands & 0.2695 & Medium \\
164 & 11 & Solomon Islands & 0.2406 & Low \\
179 & 12 & Papua New Guinea & 0.1882 & Low \\
\hline
\end{tabular}

Source: United Nations (2016) 


\section{Literature review}

\section{World e-government research - key themes and trends}

E-government research has a relatively short history of just over a decade (Molnar, Janssen, and Weerakkody 2015). The major topics in e-government literature often revolve around some specific areas, particularly e-government technology, such as the usability of e-government websites (e.g. Huang and Benyoucef 2014); infrastructure and resources (e.g. Heeks 2006); socio-economic issues, such as digital divide leading to e-government divide (Zhao, Collier, and Deng 2014); legislations and strategies (e.g. Cordella and Iannacci 2010; Margetts and Dunleavy 2013); user behaviour and intentions drawing on various technology acceptance models (e.g. Martin and Rice 2010); and cultural issues in e-government development and adoption (e.g. Zhao, Shen, and Collier 2014).

Luna-Reyes and Gil-Garcia (2014) posited that e-government has four dimensions: e-services (providing public services), e-management (improving managerial effectiveness), e-democracy (promoting democratic values and mechanisms), and e-policy (developing public policies). This proposition of Luna-Reyes et al. represents the clear trend of many research publications in focusing principally on the supply side (or government-related issues), such as strategies and policies, challenges and technical issues in providing e-government services. Zhang, Xu, and Xiao (2014) conducted a meta-analytic review of the recent literature on e-government diffusion published in leading journals and found a similar trend. Research in the literature reviewed was largely focused on four issues: (1) technological, organizational, and environmental factors influencing e-government diffusion; (2) e-government diffusion technologies and systems; (3) the influence of e-government diffusion on governments and their employees; and (4) the importance of information and communication technology (ICT) infrastructure to e-government diffusion. This supplier-centric approach suggests that the provision of services is related principally to civil servants and the structural characteristics of a government organization, rather than the needs of citizens.

A paradigm shift from supplier-centricity to citizen-centricity has taken place in recent research. The latest UN' surveys (United Nations 2012; 2014; 2016) reflect this paradigm shift by measuring and benchmarking e-participation. E-participation refers to three dimensions: information sharing between governments and citizens (also called 'e-information sharing'); consultation with citizens ('e-consultation'); and citizens' engagement in decision-making processes ('e-decision-making') (United Nations 2014). Studies show that government engagement with citizens can help improve the effectiveness of government online services (e.g. Bonsón et al. 2012).

From the citizen's perspective, research focuses largely on user behaviour towards e-government. There are various technology acceptance models that have been used for that purposes. Based upon social psychological theories, Technology Adoption Model (TAM) was introduced and developed by Davis (1989) and has been widely used in the technology adoption research. The core concept of TAM is that a person's attitude towards using an IT system is jointly determined by perceived ease of use and perceived usefulness. The TAM has been adopted by e-government research to study citizens' attitude towards e-government services. For example, Carter et al. (2016) conducted a cross-country study gauging the factors affecting citizens' 
adoption of e-government services. The study found that perceived ease of use and perceived usefulness have a significant impact on citizens' intention to use e-government services. In addition, trust of Internet and trust of government are all conducive to e-government adoption. Likewise, the study by Alomari, Woods, and Sandhu (2012) based on the TAM theory (Davis 1989) found that government website design and contents are one of the salient factors influencing citizens' adoption of e-government services. The TAM model provides a sound theoretical framework to support the shift of technology diffusion study, from focusing on the supply to the demand side. However, caution is required because research has also shown that the TAM model needs to be integrated into a broader context and include variables related to both human and social change processes (Bélanger and Carter 2012). Studies (Doong, Wang, and Foxall 2010; Zhao and Khan 2013) suggest that user behaviour, expressed through an intention to use e-government services, can be determined by various contextual factors such as socio-economic, cultural, technological (e.g. information technology and infrastructure), and legal factors.

The preceding discussion provides a glimpse of the key themes and trends of the extant world e-government literature which indicates the maturity of e-government research.

\section{Fiji e-government development and research}

\section{E-government in Fiji}

Government in Fiji established its Department for Information Technology and Computing as early as 1966, providing server capacity to government departments and agencies for decades (Hassall 2005). According to the Fiji E-government Master Plan (Fiji Government 2007), Fijian e-government initiatives were aimed to modernize public sector management through the provision of online government services to citizens, government employees and businesses. According to a report by Goundar (2009), since 2007 the Fijian government had significantly improved its online services and reached Stage 2 of the four stages, namely, emerging, enhanced, transactional, and connected services stages of e-government service development as defined by the UN e-government survey (United Nations 2008). This meant that the Fiji government had not only established an online presence but had also offered relevant information and downloadable forms as well as email contacts in order to interact with the public. The past three UN e-government surveys suggested that Fiji has made significant but uneven progress in its e-government development, jumping from 105th place in 2012 to 85th in 2014, and dropping to 96th in 2016 in UN e-government surveys (United Nations 2012, 2014, 2016).

\section{Research}

However, when it comes to scholarly research published on e-government in Fiji, our review found that there was a scarcity of well-grounded multidimensional and integrative studies into Fiji e-government diffusion. Our search for Fiji e-government literature covered a 10-year period of between 2005 and 2015, using the ABI-Inform database, the Wiley Online Library and the Emerald Journals database. We searched for articles in which 'e-government', 'Fiji', or 'the South Pacific' was used in the title, keywords, or abstract. But we found only a couple of articles in the topic area. We then searched the same terms using Google Scholar. After extensive searching, we could find a total of ten articles only. Table 2 summarizes the results. 


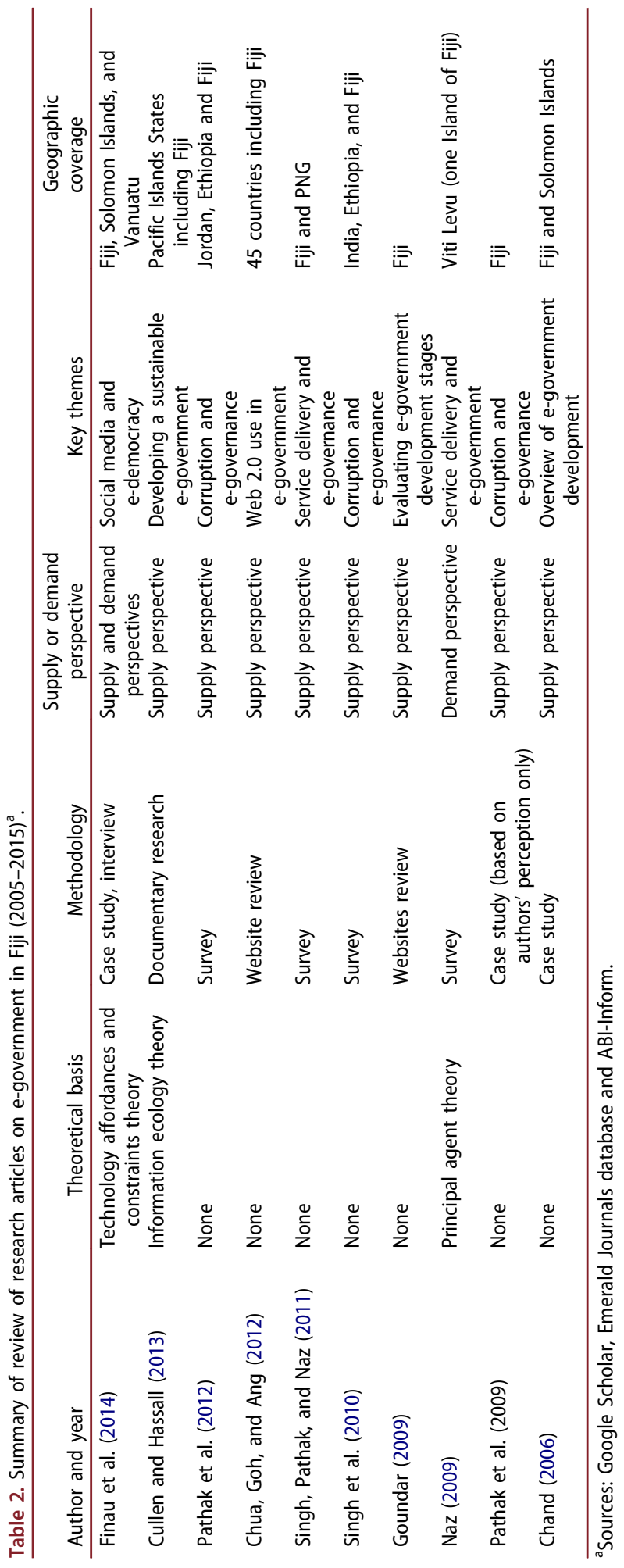


A study by Pathak et al. (2012) found that the main challenges for e-government development in Fiji were the establishment of integrated information systems through interdepartmental coordination, and achieving efficiency and effectiveness of e-services. The survey of Singh et al. (2010) found that Fiji lacked the regulations and institutions to ensure the security of e-government services. There was also a general concern that personal information may be misused or easily accessed by hackers (Chand 2006). The study by Finau et al. (2014) addressed the issues of corruption, political instability, and poor governance in Fiji, Solomon Islands, and Vanuatu, and claimed that social media could enable e-democracy in these countries.

While we acknowledged the endeavours and pioneering nature of these studies, we identified some major research issues and gaps. First, of the ten articles, only three attempted to underpin their research with theories such as information affordances and constraints theory (Finau et al. 2014) and information ecology theory (Cullen and Hassall 2013). The lack of strong theoretical grounding in e-government research has been seen as one of the major weaknesses in current e-government research literature (Yildiz 2007; Bélanger and Carter 2012). Second, the prior research tended to deal with different perspectives on Fiji e-government in an incoherent fashion. For example, three of the ten articles (Pathak et al. 2009, 2012; Singh et al. 2010) investigated the possible effect of e-government on corruption, two on service delivery, and two on government websites. Most of the studies were conducted from the supply (government) perspective. Third, eight out of the ten articles dealt with multi-country assessments rather than Fiji only. After reviewing the articles, we concluded that these multi-country studies did not provide sufficient breadth and depth to allow us to draw robust conclusions concerning Fiji e-government specifically. This study seeks to address the research gaps and develop an improved understanding of Fiji e-government diffusion through a qualitative empirical study.

\section{Theoretical basis and our research model}

The UN' worldwide survey suggests that a serious gap exists between the offer of e-government facilities and citizens' actual adoption (United Nations 2014). It is clear that the level of e-government diffusion depends on both supply and demand sides: concerning information technology infrastructure; organizational and management characteristics; economic, social, and cultural contexts, as well as citizens' adoption and participation. Studies also show that infrastructure, computerization and system integration, legislation, and the attitude of governments are some of the critical factors that determine the outcomes of e-government (Athmay and Alaa-Aldin 2013; Nkohkwo and Islam 2013; United Nations 2016). In this regard, we argue that e-government diffusion is a multifaceted phenomenon and should be addressed in a holistic and integrative way in order to entail a comprehensive inquiry. To deal with this research challenge, we chose Fountain's technology enactment framework (TEF).

Fountain's TEF is based largely on the literature of neo-institutionalism, bureaucracy, network organizations, and governance (Fountain 2001; Schellong 2007). Unlike other works that focus overwhelmingly on technology issues in e-government development, Fountain's (2001) framework illustrates how technology, organizations and institutions interact. Fountain $(2001,10)$ differentiated 'objective technology' (e.g. hardware, software and network capacity) from 'enacted technology', which is 
an outcome of the interaction between information technology and organizational forms and institutional arrangements. She argued that, 'Information technologies are not so much adopted or implemented but enacted by decision-makers' (Fountain $2011,12)$. In other words, new technology does not automatically generate organizational changes. Rather, it is organizational forms and institutional arrangements that mediate the process of change. The organizational forms refer to organizational characteristics (e.g. structure, size, personnel, and resources), whereas institutional arrangements (e.g. laws, regulations, strategy, and institutional support) refer to institutional forces that influence technology enactment. The framework was revised later in order to draw more attention to the multiple roles involved in enactment and interaction, as well as the influence between them (Fountain 2005, 2011). The multiple roles and influence refer not only to the actions of IT professionals, public servants and policymakers but also to the influence of contextual factors, such as culture, social-structure, and legal norms and politics. She used the framework specifically to study government organizations and e-government development (e.g. Fountain 2006, 2011).

The technology enactment theory developed by Fountain is influential and addresses, to some extent, the paucity of theoretical development, particularly in the current e-government literature (Yildiz 2007). The framework has been drawn on by e-government research to examine the interactions between technology, organizations, and e-government outcomes (e.g. Cordella and Iannacci 2010; Luna-Reyes and Gil-Garcia 2014; Criado, Rojas-Martín, and Gil-Garcia 2017). For example, based on Fountain's framework, Cordella and Iannacci $(2010,64)$ developed an e-government enactment framework to study the relationship between e-government policies and information systems choice and design. They found based on their empirical research that 'the outcomes of e-government policies are a combination of political, social and technological components that shape in a recursive interaction their outcomes'. GilGarcia, Renteria, and Luna-Reyes (2014) conducted a quantitative survey in Mexico to test Fountain's TEF. The results verified the TEF empirically and found that institutional arrangements have a direct impact on the enacted technology, and organizational forms have a direct impact on e-government outcomes. These findings demonstrate that the TEF is a useful model to investigate the complexity of the relationships and interactions involved in the process and outcomes of e-government.

Drawing on the TEF and the research using TEF, we developed a research model for this study. Figure 1 illustrates the model. The model explores the influences of organizational forms and institutional arrangements including political and legal, economic, social, and cultural factors on e-government diffusion outcomes which link directly with e-government enactment/development and e-government adoption/participation. We argue that the relationships are not unidirectional and the e-government diffusion outcomes can shape in turn e-government development and e-participation (i.e. citizens' e-government participation). This argument is drawn on some of the recent studies such as Wallis and Zhao (2017) who empirically proved that a reciprocal relationship exists between e-government development and government effectiveness. In addition, our model allows us to explore the interactions between supply and demand in e-government diffusion. In doing so, we are able to study e-government in a holistic and integrative way. (For a full discussion on the model, please see the 'Analysis of findings' section in this paper.) 


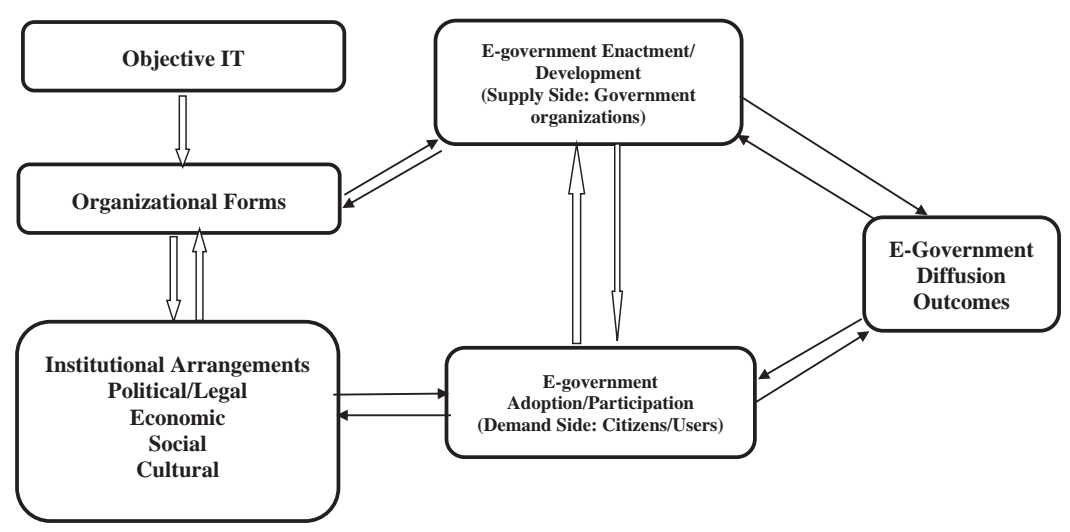

Figure 1. A holistic and integrative approach to study e-government diffusion in Fiji. Note: This model is drawn on Fountain's technology enactment framework (2001).

\section{Methods}

We used a case study research design, taking Fiji as a unit of analysis. Fiji is located in the Pacific Ocean between the equator and the South Pole. It comprises 330 islands, of which one-third are inhabited, offering a geographic layout which poses significant challenges to the development of ICT networks and connectivity. According to CIA (2014), the estimated population of the country in July 2014 was 903,207 . There are two major ethnic groups in Fiji: indigenous Fijians called iTaukei, who constitute 56.8 per cent of the population, and Indo-Fijians (of Indian descent), who constitute 37.5 per cent. English is the official language of the country while Fijian is the mother tongue of the iTaukei and Hindustani the mother tongue of the Indo-Fijians. Fiji declared independence in 1970 after nearly a century as a British colony. And, in September 2014, after several military coups, Fiji held a democratic parliamentary election. The country is one of the most developed economies in the South Pacific region, with the tourism industry being its highest foreign exchange revenue earner.

\section{Interview and process}

A total of thirty-eight semi-structured interviews were conducted for this study. As e-government concerns mainly three groups of actors: government-to-citizens, government-to-business, and government-to-government, our interviews involved government officials, citizens, and people from business communities. Some of the interviewees were e-government providers, some were users, and some were both providers and users (i.e. they provided e-government services as well as used e-government services provided by other government entities). As many people do not use e-government, we also included some non-users in our interviews. To ensure a robust and fair representation of stakeholders, we selected interviewees purposively on the basis of their involvement (or non-involvement) in e-government, their job type, managerial position, and industry/business sectors. Contact details and some of the demographic information about the interviewees were found mainly on the Internet and through personal networks. After approaching sixty-three prospective 
participants by email and telephone, thirty-eight agreed to be interviewed. Appendix A presents a list of interviewees.

The interviews took place in various locations in Fiji, mainly in Suva, Nadi, Lautoka, and Labasa, between October and November 2014. They were conducted in English, as English is the official language of Fiji and lasted, on average, 30-60 min for e-government providers, $20 \mathrm{~min}$ for e-government users, and $10 \mathrm{~min}$ for nonusers. Some of the interviews were recorded with the consent of the interviewees, with notes being taken at those interviews where interviewees preferred not to be recorded.

The main purposes of the interviews were to identify and understand major factors and challenges influencing e-government diffusion and outcomes in Fiji. Drawing on our literature review, we asked questions from both supply and demand perspectives. The key questions we asked were

For e-government providers (from the supply side):

(1) What are the major e-government initiatives/projects (including e-services) that your department has implemented?

(2) What do you think are the major issues and challenges facing e-government implementation and operations in Fiji?

(3) What are the main causes of the issues and problems?

For e-government users (from the demand side):

(1) What are the main reasons that you use e-government services?

(2) What is your experience and perception of Fiji government websites and e-government services?

For non-e-government users:

(1) What are some of the reasons that you haven't used or don't intend to use e-government?

(2) Is it likely that you will use it in future? Please explain.

The use of open-ended questions was intended to allow an in-depth understanding of the interactions and influences among multiple players. The qualitative approach and the follow-up questions also enabled us to better understand the context in which the issues arose.

\section{Data analysis method}

From a research methodology perspective, our data analysis method was based largely on the work of Miles and Huberman (1994). The process of analysis featured three concurrent sub-processes: data reduction, data display, and the drawing of conclusions. Our data reduction included qualitative content analysis of the raw interview data (transcripts and notes) collected from the interviews. A theme coding system (using theme as a coding unit) was employed in the data reduction process, during which the large amount of data was coded and categorized into key themes identified through the repeated reviewing and comparing of data (Minichiello et al. 
1990). Appendix B shows a sample of our data reduction in analysing interview transcripts.

\section{Analysis of findings}

In this section, we use our research model as an analytical lens to explore our interview data.

\section{E-government enactment and outcomes}

We define 'e-government enactment' broadly in this paper as the initiatives and mechanisms taken by government organizations to improve government performance through enacting ICT. Our interviews suggested that there had been a strong push from the (central) Government for e-government. Government departments interviewed had made important progress. For example, the government website Fiji Investment at http://www.investmentfiji.org.fj/ was well-established and had a twoway communications system with a secure login channel to handle financial transactions and online applications. The website also offered content in three different foreign languages: Japanese, Korean, and Mandarin (Interviewee No. 17). We also found through our interviews that some government websites were using Web 2.0 technologies, such as Facebook and Twitter, to engage in interactive conversations with citizens and residents. For example, the Fiji Public Services Commission had invested in human and technology resources and was able to offer, and actively engaged in, Government 2.0 services, an indication of e-consultation (Interviewee No. 5). Here are a couple of snapshots given by our interviewees on e-government enactment:

Our new initiatives include 'e-billing' (online billing), 'Mytell system' (online complaint handling system) and HR online (online leave application and approval). (Interviewee No. 3)

In a latest project by the government, they [referring to public servants] came to the villages, especially to rural schools, to give free laptops as part of an education campaign. Furthermore, the government has a one-stop shop, called Government Service Centre, which connects the services of all government ministries, and allows users to access online at the Centre whatever services are offered. (Interviewee No. 24)

I have visited the Judicial Department, Fiji Revenue and Customs Authority, and the Elections Office to lodge my applications. Actually, when I called these ministries, they referred me to their websites. The Fiji Government has done a great job by providing useful information on their websites and I think their services have improved over the years. I'm becoming more involved with government affairs. (Interviewee No. 37)

These interview data suggest that the positive interplays between enacted ICT (e.g. e-billing), organizational forms (e.g. one-stop shop, collaboration between government departments, and staff training), and institutional arrangements (e.g. e-government strategy and government supports) determine e-government enactment and e-participation which contributed to the outcomes of e-government diffusion. On the other hand, positive e-government diffusion also enhanced e-participation (see the comments made by Interviewer No. 37). This finding is consistent with the results of the quantitative survey of Wallis and Zhao (2017) which shows that a reciprocal relationship exists between e-government development and government effectiveness, 
drawing on the official datasets over a period of 9 years provided by the UN and the World Bank.

However, as we found in our interviews, e-government development in Fiji faced many challenges. Some of the issues raised were common to other countries such as lack of collaboration and coordination between government agencies. For example,

With regards to websites, there is little co-coordination and exchange of relevant information between some of government departments. For example, there is little exchange of relevant information between police and immigration departments. (Interviewee No. 29)

Other challenges were particularly related to the PICs such as scare resources (lack of basic infrastructure) and low human capital (lack of skilled workforce) that are likely to hinder e-government enactment and outcomes (Cullen and Hassall 2017). Here are two quotes:

Access is important, especially in rural areas. The government should provide generators, electricity, network connections, and proper funding in such areas (Interviewee No. 3).

The Fiji government and the people are not fully adapting to [the] latest technology. If we look at government departments, the people working there are not aware of how to use the technology. If a ministry sets up online services, all managers and employees should know how to use it. The government should place priority on up-skilling their staff first before informing the public about e-services. (Interviewee No. 5)

These challenges indicate how organizational forms and economic environment can affect adversely e-government enactment and development.

\section{E-government adoption/e-participation and outcomes}

From the perspective of citizens and users of e-government, our interviews revealed many problems and challenges, of which some were technological and economical, and some were social and cultural, and some were political and legal. For examples,

As a human resource officer, I need to access government departments' sites to get hold of forms and pay dues for employees. I face one problem, and that is the site is not interactive and I have to go physically to the government departments' and wait in the queue for long hours to hand in the forms. This is a waste of lot of time. (Interviewee No. 15)

User-end challenges have to do with affordability; a lot of people in rural areas cannot afford the Internet costs. People in my village have to travel to town when they want to access the Internet, and they pay at least FJ\$2 an hour to access [the] Internet. (Interviewee No. 24)

People in Fiji prefer face-to-face interaction or telephone conversations. We tend to do business as a person to person rather than having no one in front of you and just a PC. Maybe to some extent, it's our culture and social behaviour, we are so used to going to see a person rather than a thing like a PC. (Interviewee No. 28)

Currently, there is nowhere in Fiji to find legislations on personal information and privacy protection. Fiji needs proper legislations to prevent cyber-crime. (Interviewee No. 13)

I prefer not to use the government sites because I am not sure if it is safe and confidential. I am concerned because the Fiji police department has established a new cybercrime unit and [the] public are aware that police are monitoring websites. This has created fear within the public. (Interviewee No. 26) 
We have had so many coups in the past. This year we had our first democratic election in 8 years. We just hope we can finally have a stable and democratic government, a government that serves Fijian people and for the people, and a government that I can count on. The same is true to e-government. (Interviewee No. 10)

Using the TEF to analyse these responses to our interviews (Interviewees No. 13, 26, and 10), we can see how institutional arrangements such as legislation and political regime might affect e-government adoption and as a result, e-government diffusion outcomes. The interview data (e.g. Interviewee No. 15) indicated that the failure of governments to enact ICT caused citizens' frustration that may eventually deter their adoption of e-services. The data also suggested that there were multiple factors and their interplays that affected e-government adoption.

\section{Discussion}

Drawing on the TEF theory and taking a holistic and integrative approach, we posit that some of the key problems deterring e-government diffusion found in this study (e.g. access issue, lack of computer and Internet skills, unaffordability of computers and the Internet, and citizens' preference for communication) were rooted in Fiji's political, social, economic, and cultural environments. A study by Bélanger and Carter (2009) indicated that socio-economic, demographic and skill factors all significantly influence the level of e-government adoption. Fiji, like other PICs, has been hampered by the digital divide, in particular in rural and remote areas. Digital divide is often referred to as a marked gap in access to, and use of, ICT devices (International Telecommunication Union [ITU] 2011). Empirical research suggests that e-government diffusion is adversely affected by the digital divide because e-government requires individual education and training in order to develop the necessary computer and Internet knowledge and skills. As a result, the digital divide also leads to the e-government divide (Björn, Elena, and Ralf 2012). Therefore, bridging the e-government divide requires governments to tackle the digital divide as well.

E-government diffusion relies on a reliable and affordable communication market (Cullen and Hassall 2017). Our findings show that high ICT costs make e-government services too expensive for citizens and businesses (e.g. Interviewee No. 24). There are two main factors that contribute to the high costs in Fiji and other PICs. First, communities in PICs are in most cases isolated by vast stretches of ocean. The only viable telecommunications technologies to bridge the distances are satellite and submarine cables, which are costly to build and maintain. Second, Fiji International Telecommunications Limited is a sole owner of Fiji's fixed network provider and major retailer Telecom Fiji Limited and also a 51 per cent owner of Vodafone Fiji (Reddy 2013). This monopoly of telecommunications market pushes ICT prices unreasonably high (Louey-Gung 2017), which is one of the key deterrents to e-government access and use as suggested in our findings.

As found in our interview (Interviewee No. 10), the political environment in Fiji has caused concerns and affected the credibility of the government as well as e-government development. The study by Cullen and Hassall (2017) suggest that e-government progress in Fiji has been hampered by several political crisis caused by military coups and subsequent emigration of skilled and highly qualified citizens. Over the past 30 years, Fiji has witnessed four military coups (two in 1987, one in 2000 , and one in 2006). In addition to the instable political environment, the coups 
have deterred significantly the economic growth and adversely affected foreign investment in Fiji. Compounded with the economic loss was the massive emigration of skilled workforce which affected negatively the service standard of the government sector (Duncan, Codippily, and Duituturaga 2014). This indicates that the various institutional forces, political, economic, and social, are all interrelated and acted on each other affecting e-government diffusion in Fiji.

The participants in our interviews expressed serious concerns on cyber security and privacy issues due to lack of legislation (e.g. Interviewees No. 13 and 26), which affected their confidence in using e-government services. With increasing pressure from citizens for e-participation (United Nations 2014, 2016), we consider that it is even more important for government agencies to have adequate privacy practices to protect e-government users. Based on our findings, we argue that the information privacy issue raised here goes beyond e-government; that it could have political, legal, social, and cultural aspects. Due to the nature of the problem, Bélanger and Crossler (2011) called for a multilevel-analysis approach involving individuals, groups, organizations, governments, and society as a whole.

In terms of the effect of culture, our study found that culture being an important institutional force plays a crucial role in Fiji e-government adoption. Prior studies suggest that culture influences citizens' behavioural intentions regarding the adoption of e-government services (Khalil 2011; Zhao and Khan 2013). The findings from our interviews (such as Interviewee No. 28) suggest that Fijian culture may not be congruent with developing e-government services which rely primarily on impersonal and electronic communications. Fijians prefer personal and close contact with their government. In this regard, e-government services may need to be made more interactive and engaging in order to attract users, for example through social networking tools, to engage in e-consultation with their citizens. A recent study by Porumbescu (2016) found that greater use of government social media accounts has a significantly positive effect on trust in government. Another empirical study by Vicente and Novo (2014) highlighted the increasing importance of online social networks as catalysts for citizens' e-participation (i.e. e-government participation). According to a study by Hofstede, Hofstede, and Minkov (2010), Fiji is considered a collectivistic society. The recent study by Wadley, Bumpus, and Green (2014) also found that Fiji has a community-oriented culture. Interactions within the social networks in these communities could play an important role in e-government adoption. On this basis, Fiji governments need to take into account the influence of culture when formulating policies and strategies for e-government diffusion.

\section{Research contributions and implications}

To obtain a comprehensive understanding of e-government diffusion in Fiji, we have taken a holistic and integrative approach to this research, drawing on Fountain's (2001) TEF. This approach facilitated an open-ended inquiry, not restricted to any single aspect of e-government, and a focus on the interrelationships and interactions among multiple factors related to e-government diffusion from both the demand and supply sides. This approach also remedied some of the limitations affecting current e-government research, which is often undertaken in a rather ad hoc fashion (Shareef et al. 2011). As a result, this study makes valuable contributions to the knowledge and 
practice of, as well as the research into, e-government diffusion not only in Fiji but also potentially in the Pacific region and beyond.

This study offers three contributions and implications for future research. First, to our knowledge, this study is the first empirical study that explores Fiji e-government diffusion in a holistic and integrative way. By doing so, we are able to study the issues related to e-government from both supply and demand sides, while taking into account the contextual factors surrounding the issues. Although some academic research has been published about Fiji e-government, it has not been holistic and integrative, while it has also lacked theoretical underpinnings as well as depth and breadth. The results of the present study enrich the world literature with a wellgrounded and comprehensive Fiji case study and provide empirical evidence for future research about Fiji e-government diffusion. For example, we found through this study that some of Fijian cultural orientations may deter e-government diffusion. Future study could study and test what and how specific cultural practices in Fiji have a significant effect on e-government diffusion. Second, this study demonstrates that by using our research model, developed from TEF, we are able to capture a holistic picture and explore integratively the multiple relationships and interactions in the process of e-government diffusion. Our research model should aid in developing a more robust conceptual model for future e-government diffusion research. Fountain's (2001) TEF suggests that the relationship between government organizations and technology in the digital era is not unidirectional but bidirectional. Likewise, the relationships between organizational forms and institutional arrangements, and e-government diffusion are likely to be bidirectional or reciprocal. A conceptual and empirical inquiry into the nature of these relationships should provide fertile ground for further development of our understanding of e-government diffusion. Third, Fiji, like other PCIs, faces some unique challenges such as geographic isolation and frequent natural disasters (United Nations 2014). E-government research into the unique challenges facing PICs is still in its infancy (Cullen and Hassall 2013). This Fiji case study could pave the way for further empirical research into the unique challenges facing PICs in e-government diffusion.

This study has important practical value. Given that Fiji e-government development was ranked highest among PICs (United Nations 2016), the findings from Fiji are likely to be useful for policymakers in the PIC region in regards to Fiji's e-government practices, its experience and major issues. This empirical case study helps better understand what and how information technology, organizational forms, and institutional forces affect e-government diffusion. In addition, the way we have studied the e-government diffusion could help governments and policymakers understand and tackle e-government issues and challenges in a holistic and integrative way when developing national and local e-government diffusion strategies.

\section{Limitations and future research}

This study has at least two challenges and limitations: its research scope and its methodology. In terms of research scope, as discussed above, taking a holistic and integrative approach had a clear advantage in permitting an understanding of both e-government suppliers and citizens as well as the influences of various institutional arrangements on e-government diffusion. On the down-side, this led to the practical challenge of looking across different and multiple domains, such as technology, 
public administration, and various institutional forces. The present study attempted to address this challenge through a focused empirical case study of Fiji. Although this case study addresses the paucity of empirical and holistic studies into Fiji e-government diffusion to some extent, caution must be taken to draw any generalization from this single case study design and the findings. For example, we took Fiji as a nation and a unit of analysis in our study. In this regard, when it comes to its culture, we treated it as a national culture. Fiji has two major ethnic groups - indigenous Fijians (also referred to as iTaukei) and Indo-Fijians. Previous research found that the two ethnic groups have distinctive cultures and lifestyles (Cato 1955; Chand and White 2006). A study by Sharma and Lawrence (2009) observed that indigenous Fijians have strong religious values and hierarchical systems (or chiefdoms), whereas the Indo-Fijians have a loose knit social framework and endeavour to preserve their ancestral and customary practices. Given the small number of the participants in our study, we were not able to study the cultural differences and their influence on e-government adoption.

Furthermore, interviewee bias can be a problem (Talmy 2010). Moreover, the perceptions and opinions of the participants in our interviews were personal and may not be accurate in all contexts. To attempt to reduce the risk of individual bias, we interviewed a total of thirty-eight stakeholders from diverse backgrounds. To achieve a higher level of convergent validity in our study, we suggest that further rigorous and empirical research should be conducted, such as a nationwide quantitative survey. Nevertheless, we firmly believe that the line of inquiry and approach that we have taken here provides a solid foundation for further theoretical and empirical research.

\section{Conclusion}

The shift from traditional government to e-government services requires fundamental changes in the mindsets of governments and citizens alike. In this transformation process, government organizations determine the outcomes of the transformation (Fountain 2005). During the technology enactment process, government organizations need to take into consideration citizens' needs, their influences and roles in order to generate effective outcomes from e-government. On the other hand, the behavioural intention of citizens (including institutional users) is of critical importance for e-government development (e.g. Davis 1989; Zhao and Khan 2013). Drawing on Fountain's TEF, our research model allowed us to explore in a holistic and integrative way, the interactions between supply and demand as well as the contextual issues in e-government diffusion.

This study makes a valuable addition to the extant e-government literature by contributing an empirical and case study of Fiji using TEF. It is our hope that the case study can assist policy-makers to better understand the complex relationships and some of the key issues in e-government diffusion and, therefore, make informed decisions in order to achieve the ultimate strategic goal of creating a connected and responsive government in Fiji. We also believe that our Fijian study provides an empirical insight into the unique challenges in e-government diffusion not only in Fiji but also in the PIC region.

\section{Disclosure statement}

No potential conflict of interest was reported by the authors. 


\section{Notes on contributors}

Dr Fang Zhao is a professor of management in the School of Business and Law, Edith Cowan University in Australia. She is a passionate researcher with a successful track record of research mainly in the areas related to e-government diffusion, digital entrepreneurship, and cross-cultural management. Since receiving her $\mathrm{PhD}$ in 1998, she has published around hundred peer-reviewed quality research works internationally. Many of her works were published in top-tier journals. Professor Zhao has led and completed a large number of research and consulting projects funded by governments, industry/business, and universities.

Dr Suwastika Naidu is a lecturer at the University of the South Pacific, Suva, Fiji Islands. Her areas of research interest include operations management, e-government, finance, supply chain management, value chain analysis, and human resource management.

Dr Gurmeet Singh is an associate professor at the University of the South Pacific, Suva, Fiji Islands. His research areas include e-governance, service delivery, and customer satisfaction in South Pacific region.

Aarti Sewak is a lecturer at the University of the South Pacific, Suva, Fiji Islands. Her areas of research interest include social marketing and e-government.

Dr Anand Chand is an associate professor at the University of the South Pacific, Suva, Fiji Islands. His research areas include human resource management in the Fiji Islands and e-government.

Maureen Karan a lecturer at the University of the South Pacific, Suva, Fiji Islands. Her areas of research interests include the privatization of state-owned enterprises in Fiji and e-government diffusion.

\section{References}

Alomari, M., P. Woods, and K. Sandhu. 2012. "Predictors for E-Government Adoption in Jordan: Deployment of an Empirical Evaluation Based on a Citizen-Centric Approach." Information Technology and People 25 (2): 207-234. doi:10.1108/09593841211232712.

Athmay, A. L., and A. R. Alaa-Aldin. 2013. "E-Governance in Arab Countries: Status and Challenges." Global Journal of Business Research 7 (5): 79-98.

Bélanger, F., and L. Carter. 2009. "The Impact of the Digital Divide on E-Government Use." Communications of the ACM 52 (4): 132-135. doi:10.1145/1498765.

Bélanger, F., and L. Carter. 2012. "Digitizing Government Interactions with Constituents: An Historical Review of E-Government Research in Information Systems." Journal of Association for Information System 13 (5): 363-394.

Bélanger, F., and R. E. Crossler. 2011. "Privacy in the Digital Age: A Review of Information Privacy Research in Information Systems.” MIS Quarterly 35 (4): 1017-1042.

Björn, N., G. Elena, and P. Ralf. 2012. "The Digital Divide Vs. The E-Government Divide: Do SocioDemographic Variables (Still) Impact E-Government Use among Onliners?" Proceedings of ECIS 2012, Paper 199. http://aisel.aisnet.org/ecis2012/199

Bonsón, E., L. Torres, S. Royo, and F. Flores. 2012. "Local E-Government 2.0: Social Media and Corporate Transparency in Municipalities." Government Information Quarterly 29 (2): 123-132. doi:10.1016/j.giq.2011.10.001.

Carter, L., V. Weerakkody, B. Phillips, and Y. K. Dwivedi. 2016. "Citizen Adoption of E-Government Services: Exploring Citizen Perceptions of Online Services in the United States and United Kingdom." Information Systems Management 33 (2): 124-140. doi:10.1080/ 10580530.2016 .1155948 .

Cato, A. C. 1955. "Fijians and Fiji-Indians: A Culture-Contact Problem in the South Pacific." Oceania 26 (1): 14-34. doi:10.1002/ocea.1955.26.issue-1.

Chand, A. 2006. "E-Government in the South Pacific Region: Case Studies from Fiji and Solomon Islands." Journal of United Nations Regional Development Dialogue 27 (2): 64-72. 
Chand, P., and M. White. 2006. "The Influence of Culture on Judgments of Accountants in Fiji." Australian Accounting Review 16 (3): 82-88. doi:10.1111/j.1835-2561.2006.tb00048.x.

Chua, A. Y., D. H. Goh, and R. P. Ang. 2012. "Web 2.0 Applications in Government Web Sites: Prevalence, Use and Correlations with Perceived Web Site Quality." Online Information Review 36 (2): 175-195. doi:10.1108/14684521211229020.

CIA (Central Intelligence Agency). 2014. The World Factbook. Washington, DC: Potomac Books.

Cordella, A., and F. Iannacci. 2010. "Information Systems in the Public Sector: The e-Government Enactment Framework.” The Journal of Strategic Information Systems 19 (1): 52-66. doi:10.1016/j. jsis.2010.01.001.

Corydon, B., V. Ganesan, and M. Lundqvist. 2016. "Transforming Government through Digitization." McKinsey \& Company. http://www.mckinsey.com/industries/public-sector/ourinsights/transforming-government-through-digitization

Criado, J. I., F. Rojas-Martín, and J. R. Gil-Garcia. 2017. "Enacting Social Media Success in Local Public Administrations: An Empirical Analysis of Organizational, Institutional, and Contextual Factors." International Journal of Public Sector Management 30 (1): 31-47. doi:10.1108/IJPSM-032016-0053.

Cullen, R., and G. Hassall. 2013. "An Information Ecology Approach to Sustainable E-Government among Small Island Developing States in the Pacific." In Proceedings of the 46th Hawaii International Conference on System Sciences (HICSS '13), edited by Ralph H. Sprague, Jr., 19221931. Washington, DC: IEEE.

Cullen, R., and G. Hassall., eds. 2017. "E-Government in Pacific Island Countries." In Achieving Sustainable E-Government in Pacific Island States, 3-32. New York: Springer International.

Davis, F. D. 1989. "Perceived Usefulness, Perceived Ease of Use, and User Acceptance of Information Technology." MIS Quarterly 13 (3): 319-340. doi:10.2307/249008.

Doong, H. S., H. C. Wang, and G. R. Foxall. 2010. "Psychological Traits and Loyalty Intentions Towards e-Government Services.” International Journal of Information Management 30 (5): 457464. doi:10.1016/j.ijinfomgt.2010.01.007.

Duncan, R., H. Codippily, E. Duituturaga and R. Bulatale. 2014. Identifying Binding Constraints in Pacific Island Economies. Honolulu: East-West Center.

Fiji Government. 2007. Fiji E-Government Master Plan. Suva: Fiji Government.

Finau, G., A. Prasad, R. Kant, J. V. Tarai, S. Logan, and J. Cox. 2014. "Social Media and E-Democracy in Fiji, Solomon Islands and Vanuatu." In Proceedings of the Twentieth Americas Conference on Information Systems,3929-3937. Red Hook, NY: Curran Associates.

Fountain, J. 2005. Central Issues in the Political Development of the Virtual State. The Network Society: From Knowledge to Policy. Washington, DC: Center for Transatlantic Relations.

Fountain, J. E. 2001. Building the Virtual State: Information Technology and Institutional Change. Washington, DC: Brookings Institution Press.

Fountain, J. E. 2006. "Enacting Technology in Networked Governance: Developmental Processes of Cross-Agency Arrangements.” National Center for Digital Government Working Paper Series 16. http://scholarworks.umass.edu/cgi/viewcontent.cgi?article=1018\&context=ncdg

Fountain, J. E. 2011. "Bringing Institutions Back in to Strategic Management: The Politics of Digitally Mediated Institutional Change." National Center for Digital Government Working Papers 11 (001): 1-48.

Gil-Garcia, J. R., C. Renteria, and L. F. Luna-Reyes. 2014. "Enacting Collaborative Electronic Government: Empirical Evidence and Lessons for Developing Countries." In Proceedings of the 47th Hawaii International Conference on System Sciences (HICSS '14), edited by Ralph H.Sprague, Jr., 2253-2262. Washington, DC: IEEE.

Goundar, S. 2009. “An Evaluation of Fiji's E-Government Status: Assessed according to a Report on Benchmarking E-Government Progress." Proceedings of the Association for Information Systems Special Interest Group for ICT in Global Development. http://unpan1.un. org/intradoc/groups/ public/documents/un-dpadm.

Hassall, G. 2005. "ITC Policy and Practice in the Fiji Islands." In Encyclopaedia of Developing Regional Communities with Information and Communication Technology, edited by S. Marshall, 471-474. Hershey: IGI Global.

Heeks, R. 2006. Implementing and Managing E-Government: An International Text. London: Sage Publications. 
Hofstede, G., G. J. Hofstede, and M. Minkov. 2010. Cultures and Organizations: Software of the Mind. Revised and Expanded. 3rd ed. New York: McGraw-Hill.

Huang, Z., and M. Benyoucef. 2014. "Usability and Credibility of E-Government Websites." Government Information Quarterly 31 (4): 584-595. doi:10.1016/j.giq.2014.07.002.

IMF (International Monetary Fund). 2013. Republic of Fiji: Staff Report for the 2013 Article IV Consultation. Accessed May 15 2016. https://www.imf.org/external/pubs/ft/scr/2013/cr13370.pdf

International Telecommunication Union (ITU). 2011. Measuring the Information Society Annual Report. Geneva: ITU.

Khalil, E. M. 2011. "E-Government Readiness: Does National Culture Matter?" Government Information Quarterly 28: 388-399. doi:10.1016/j.giq.2010.06.011.

Louey-Gung, B. 2017. "Regulation, Access and Connectivity in Pacific Island States." In Achieving Sustainable E-Government in Pacific Island States, edited by R. Cullen and G. Hassall, 89-116. Cham: Springer International Publishing.

Luna-Reyes, L. F., and J. R. Gil-Garcia. 2014. "Digital Government Transformation and Internet Portals: The Co-Evolution of Technology, Organizations, and Institutions." Government Information Quarterly 31 (4): 545-555. doi:10.1016/j.giq.2014.08.001.

Margetts, H., and P. Dunleavy. 2013. "The Second Wave of Digital-Era Governance: A Quasi Paradigm for Government on the Web." Philosophical Transactions of the Royal Society A: Mathematical, Physical and Engineering Sciences 371: 1987. doi:10.1098/rsta.2012.0512.

Martin, N. J., and J. L. Rice. 2010. "Building Better Government IT: Understanding Community Beliefs and Attitudes toward Smart Card Technologies." Behaviour \& Information Technology 29 (4): 433-444. doi:10.1080/01449291003767938.

Miles, M. B., and A. M. Huberman. 1994. Qualitative Data Analysis: A Sourcebook. Beverly Hills: Sage Publications.

Minichiello, V., R. Aroni, E. Timewell, and L. Alexander. 1990. "Interview Processes." In In-depth Interviewing: Researching People, 107-145. South Melbourne: Longman Cheshire.

Molnar, A., M. Janssen, and V. Weerakkody. 2015. "E-Government Theories and Challenges: Findings from a Plenary Expert Panel." In Proceedings of the 16th Annual International Conference on Digital Government Research, 160-166. New York: ACM.

Naz, R. 2009. "E-Governance for Improved Public Service Delivery in Fiji." Journal of Service Science \& Management 3: 190-203. doi:10.4236/jssm.2009.23023

Nkohkwo, Q. N., and M. S. Islam. 2013. "Challenges to the Successful Implementation of E-Government Initiatives in Sub-Saharan Africa: A Literature Review.” Electronic Journal of e-Government 11 (2): 253-253.

Pathak, R. D., R. Belwal, G. Singh, R. Naz, K. A. Zoubi, and R. F. I. Smith. 2012. “Citizens' Perception of Corruption and E-Governance in Jordon, Ethiopia and Fiji-The Need for a Marketing Approach." Electronic Government: An International Journal 9 (3): 309-332. doi:10.1504/EG.2012.048005.

Pathak, R. D., R. Naz, M. H. Rahman, R. F. I. Smith, and K. Nayan Agarwal. 2009. "E-governance to Cut Corruption in Public Service Delivery: A Case Study of Fiji." International Journal of Public Administration 32 (5): 415-437.

Porumbescu, G. A. 2016. "Comparing the Effects of E-Government and Social Media Use on Trust in Government: Evidence from Seoul, South Korea.” Public Management Review 18 (9): 13081334. doi:10.1080/14719037.2015.1100751.

Reddy, M. 2013. "Telecommunications Market in a Small Economy: Is There a Need for Price Control?" Asian Economic and Financial Review 3 (7): 843.

Schellong, A. 2007. "Extending the Technology Enactment Framework." PNG Working Paper No PNG07-003, Program on Networked Governance, 1-9. Boston, MA: John F. Kennedy School of Government, Harvard University.

Shareef, M. A., V. Kumar, U. Kumar, and Y. K. Dwivedi. 2011. "E-Government Adoption Model (GAM): Differing Service Maturity Levels.” Government Information Quarterly 28 (1): 17-35. doi:10.1016/j.giq.2010.05.006.

Sharma, U., and S. Lawrence. 2009. "Global Remedies for Local Needs: Corporate Governance and Public Sector Reforms in Fiji." Pacific Accounting Review 21 (3): 260-285. doi:10.1108/ 01140580911012502. 
Singh, G., R. D. Pathak, and R. Naz. 2011. "Service Delivery through E-Governance: Perception and Expectation of Customers in Fiji and PNG." Public Organization Review: A Global Journal 11 (4): 371-384. doi:10.1007/s11115-010-0135-2.

Singh, G., R. D. Pathak, R. Naz, and R. Belwal. 2010. "E-Governance for Improved Public Sector Service Delivery in India, Ethiopia and Fiji." International Journal of Public Sector Management 23 (3): 254-275. doi:10.1108/09513551011032473.

Talmy, S. 2010. "The Interview as Collaborative Achievement: Interaction, Identity, and Ideology in a Speech Event." Applied Linguistics 32 (1): 25-42.

United Nations. 2012. UN E-Government Survey. New York: United Nations.

United Nations. 2014. "E-Government Survey for the Future We Want." Accessed March 202015. http://unpan3.un.org/egovkb/portals/egovkb/documents/un/2014-survey/e-gov_complete_sur vey-2014.pdf

United Nations. 2016. "The United Nations E-Government Survey 2016: E-Government in Support of Sustainable Development.” Accessed October 11, 2016. https://publicadministration.un.org/ egovkb/en-us/Reports/UN-E-Government-Survey-2016

United Nations. 2008. UN E-Government Survey 2008: From E-government to Connected Governance. New York: United Nations.

Vicente, M. R., and M. Novo. 2014. "An Empirical Analysis of E Participation: The Role of Social Networks and E Government over Citizens' Online Engagement.” Government Information Quarterly 31 (3): 379-387. doi:10.1016/j.giq.2013.12.006.

Wadley, G., A. Bumpus, and R. Green. 2014. "Citizen Involvement in the Design of Technology for Climate Change Adaptation Projects in the Pacific." Paper presented at OzCHI 2015: Being human, Melbourne, Australia, December 7-10. http://people.eng.unimelb.edu.au/gwadley/pubs/ OzCHI2014-ClimateChange.pdf

Wallis, J., and F. Zhao. 2017. "E-Government Development and Government Effectiveness: A Reciprocal Relationship." International Journal of Public Administration. doi:10.1080/ 01900692.2016.1273950.

World Bank. 2008. "Definition of E-Government." Accessed July 9, 2009. http://web.worldbank.org/ W B S I T E / E X T E R N A L / T O P I C S / E X T I N F O R M A T I O N A N D C O M MUNICATIONANDTECHNOLOGIES/EXTEGOVERNMENT/0, contentMDK:20507153 menuPK:702592 pagePK:148956 piPK:216618 theSitePK:702586,00.html

Yildiz, M. 2007. "E-Government Research: Reviewing the Literature, Limitations, and Ways Forward." Government Information Quarterly 24 (3): 646-665. doi:10.1016/j.giq.2007.01.002.

Zhang, H., X. Xu, and J. Xiao. 2014. "Diffusion of E-Government: A Literature Review and Directions for Future Directions." Government Information Quarterly 31 (4): 631-636. doi:10.1016/j.giq.2013.10.013.

Zhao, F., A. Collier, and H. Deng. 2014. "A Multidimensional and Integrative Approach to Study Global Digital Divide and E-Government Development.” Information Technology and People 27 (1): 38-62. doi:10.1108/ITP-01-2013-0022.

Zhao, F., K. N. Shen, and A. Collier. 2014. "Effects of National Culture on E-Government Diffusion: A Global Study of 55 Countries." Information \& Management 51 (8): 1005-1016. doi:10.1016/j. im.2014.06.004.

Zhao, F., and S. Khan. 2013. "An Empirical Study of E-Government Service Adoption: Culture and Behavioral Intention." International Journal of Public Administration 36 (10): 710-722. doi:10.1080/01900692.2013.791314. 


\section{Appendices}

\section{Appendix A. A list of participants in interviews ${ }^{a}$}

\begin{tabular}{|c|c|c|c|c|c|c|c|}
\hline ID & Position & Industry/sector & $\begin{array}{l}\text { Provider/ } \\
\text { user }\end{array}$ & ID & Position & Industry/sector & $\begin{array}{l}\text { Provider/ } \\
\text { user }\end{array}$ \\
\hline 1 & $\begin{array}{l}\text { Executive } \\
\text { assistant }\end{array}$ & $\begin{array}{l}\text { Employment } \\
\text { Relations Tribunal } \\
\text { (government) }\end{array}$ & Provider & 20 & Businessman & Printing (private) & Non-user \\
\hline 2 & Entrepreneur & Trade (private) & User & 21 & $\begin{array}{l}\text { Assistant } \\
\text { manager }\end{array}$ & $\begin{array}{l}\text { Housing } \\
\text { (government) }\end{array}$ & Provider \\
\hline 3 & $\begin{array}{l}\text { Senior } \\
\text { manager }\end{array}$ & IT (public) & Provider & 22 & $\begin{array}{l}\text { Procurement } \\
\text { officer }\end{array}$ & $\begin{array}{l}\text { Finance } \\
\quad \text { (government) }\end{array}$ & User \\
\hline 4 & $\begin{array}{l}\text { Web } \\
\text { developer }\end{array}$ & $\begin{array}{l}\text { City Council } \\
\text { (government) }\end{array}$ & Provider & 23 & Clerical officer & $\begin{array}{l}\text { Telecommunication } \\
\text { (private) }\end{array}$ & User \\
\hline 5 & $\begin{array}{l}\text { Middle } \\
\text { manager }\end{array}$ & $\begin{array}{l}\text { Public Service } \\
\text { Commission } \\
\text { (public) }\end{array}$ & Provider & 24 & Farmer & Poultry (private) & User \\
\hline 6 & $\begin{array}{l}\text { Evaluation } \\
\quad \text { researcher }\end{array}$ & $\begin{array}{l}\text { Non-governmental } \\
\text { organization } \\
\text { (NGO) }\end{array}$ & User & 25 & $\begin{array}{l}\text { Marketing } \\
\text { manager }\end{array}$ & Trade (private) & User \\
\hline 7 & $\begin{array}{l}\text { IT manager } \\
\text { (private) }\end{array}$ & $\begin{array}{l}\text { Banking and } \\
\text { Finance (private) } \\
\text { Non-user }\end{array}$ & User & 26 & Sales & representative & Trade \\
\hline 8 & $\begin{array}{l}\text { Tertiary } \\
\text { student }\end{array}$ & $\begin{array}{l}\text { Higher Education } \\
\text { (public) }\end{array}$ & User & 27 & $\begin{array}{l}\text { Tertiary } \\
\text { student }\end{array}$ & $\begin{array}{l}\text { Higher Education } \\
\text { (public) }\end{array}$ & User \\
\hline 9 & $\begin{array}{l}\text { Middle } \\
\text { manager }\end{array}$ & IT (government) & $\begin{array}{l}\text { Provider } \\
\text { and user }\end{array}$ & 28 & Office worker & $\begin{array}{l}\text { Ministry of iTaukei } \\
\text { Affairs } \\
\text { (government) }\end{array}$ & Provider \\
\hline 10 & $\begin{array}{l}\text { Tertiary } \\
\text { student }\end{array}$ & $\begin{array}{l}\text { Higher Education } \\
\text { (public) }\end{array}$ & User & 29 & $\begin{array}{l}\text { Senior } \\
\text { manager }\end{array}$ & Fiji Telecom (private) & $\begin{array}{l}\text { Provider } \\
\text { and } \\
\text { user }\end{array}$ \\
\hline 11 & $\begin{array}{l}\text { Project } \\
\text { manager }\end{array}$ & $\begin{array}{l}\text { Construction } \\
\text { (government) }\end{array}$ & User & 30 & $\begin{array}{l}\text { Senior } \\
\quad \text { customs } \\
\text { officer }\end{array}$ & $\begin{array}{l}\text { FIRCA }^{\text {b }} \\
\text { (government) }\end{array}$ & $\begin{array}{l}\text { Provider } \\
\text { and } \\
\text { user }\end{array}$ \\
\hline 12 & Academic & $\begin{array}{l}\text { Higher Education } \\
\text { (public) }\end{array}$ & User & 31 & Manager ICT & $\begin{array}{l}\text { Housing Authority } \\
\text { (government) }\end{array}$ & Provider \\
\hline 13 & Web master & $\begin{array}{l}\text { Web Design } \\
\text { (private) }\end{array}$ & Provider & 32 & $\begin{array}{l}\text { Middle } \\
\text { manager }\end{array}$ & $\begin{array}{l}\text { Ministry of Urban } \\
\text { Development } \\
\text { (government) }\end{array}$ & $\begin{array}{l}\text { Provider } \\
\text { and } \\
\text { user }\end{array}$ \\
\hline 14 & $\begin{array}{l}\text { Web } \\
\text { designer }\end{array}$ & Education (public) & User & 33 & $\begin{array}{l}\text { Middle } \\
\text { manager }\end{array}$ & $\begin{array}{l}\text { Water Authority } \\
\text { (public) }\end{array}$ & Provider \\
\hline 15 & HR officer & $\begin{array}{l}\text { Hardware Retail } \\
\text { (private) }\end{array}$ & User & 34 & Police officer & $\begin{array}{l}\text { Defence } \\
\text { (government) }\end{array}$ & User \\
\hline 16 & Police officer & Police (government) & Provider & 35 & Office worker & $\begin{array}{l}\text { National planning } \\
\text { (government) }\end{array}$ & $\begin{array}{l}\text { Provider } \\
\text { and } \\
\text { user }\end{array}$ \\
\hline 17 & ICT officer & $\begin{array}{l}\text { Ministry of } \\
\text { Information } \\
\text { (government) }\end{array}$ & Provider & 36 & Secretary & $\begin{array}{l}\text { Judiciary } \\
\quad \text { (government) }\end{array}$ & $\begin{array}{l}\text { Provider } \\
\text { and } \\
\text { user }\end{array}$ \\
\hline 18 & $\begin{array}{l}\text { Junior } \\
\text { manager }\end{array}$ & $\begin{array}{l}\text { Telecommunication } \\
\text { (private) }\end{array}$ & Non-user & 37 & Salesman & Trade (private) & User \\
\hline 19 & $\begin{array}{l}\text { Tertiary } \\
\text { student }\end{array}$ & $\begin{array}{l}\text { Higher Education } \\
\text { (private) }\end{array}$ & User & 38 & Hotel Worker & Service (private) & User \\
\hline
\end{tabular}

${ }^{a}$ To ensure the anonymity and confidentiality of the participants, we chose not to specify in great detail their roles and affiliations.

FIRCA: Fiji Revenue and Customs Authority. 


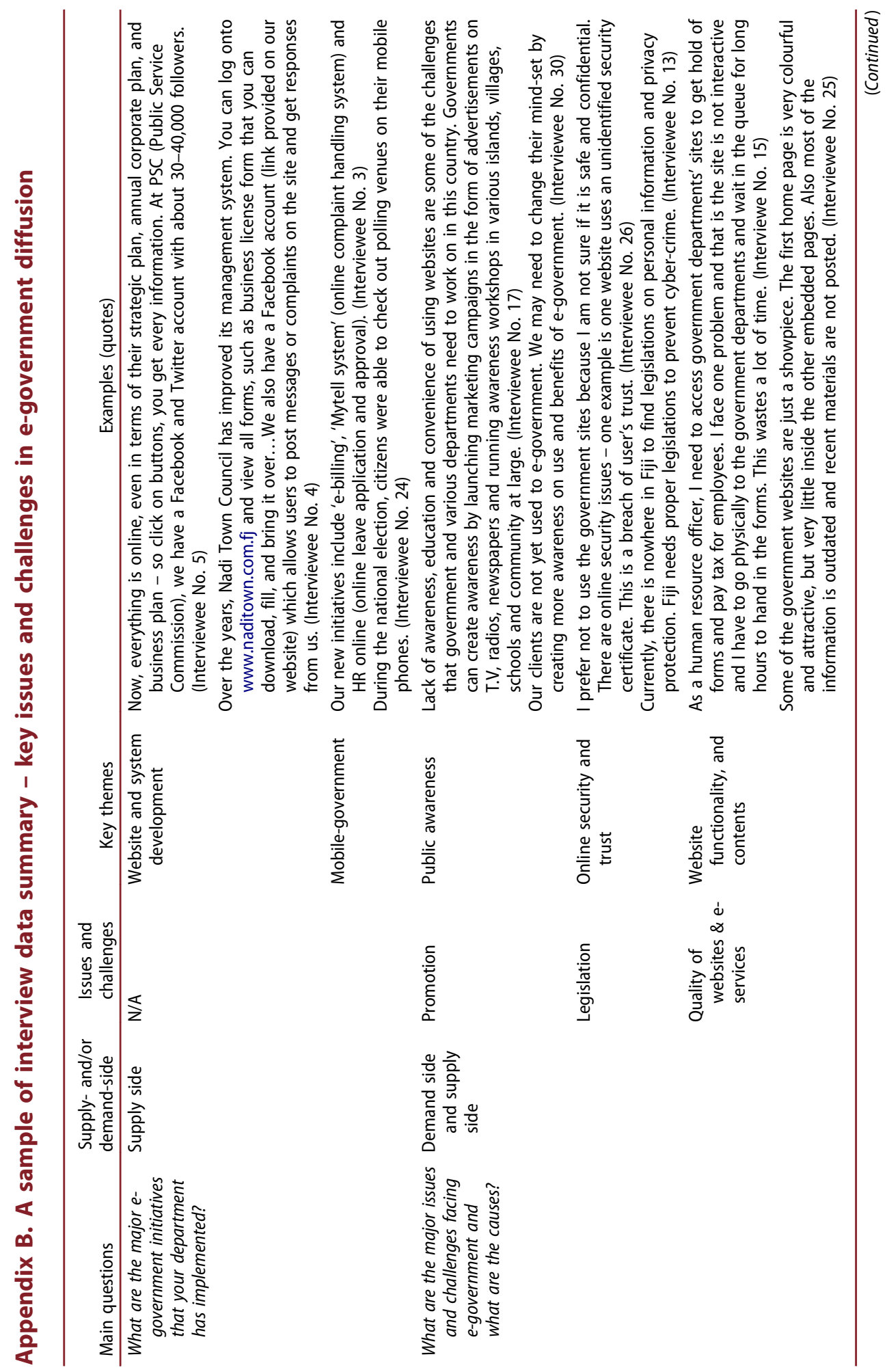




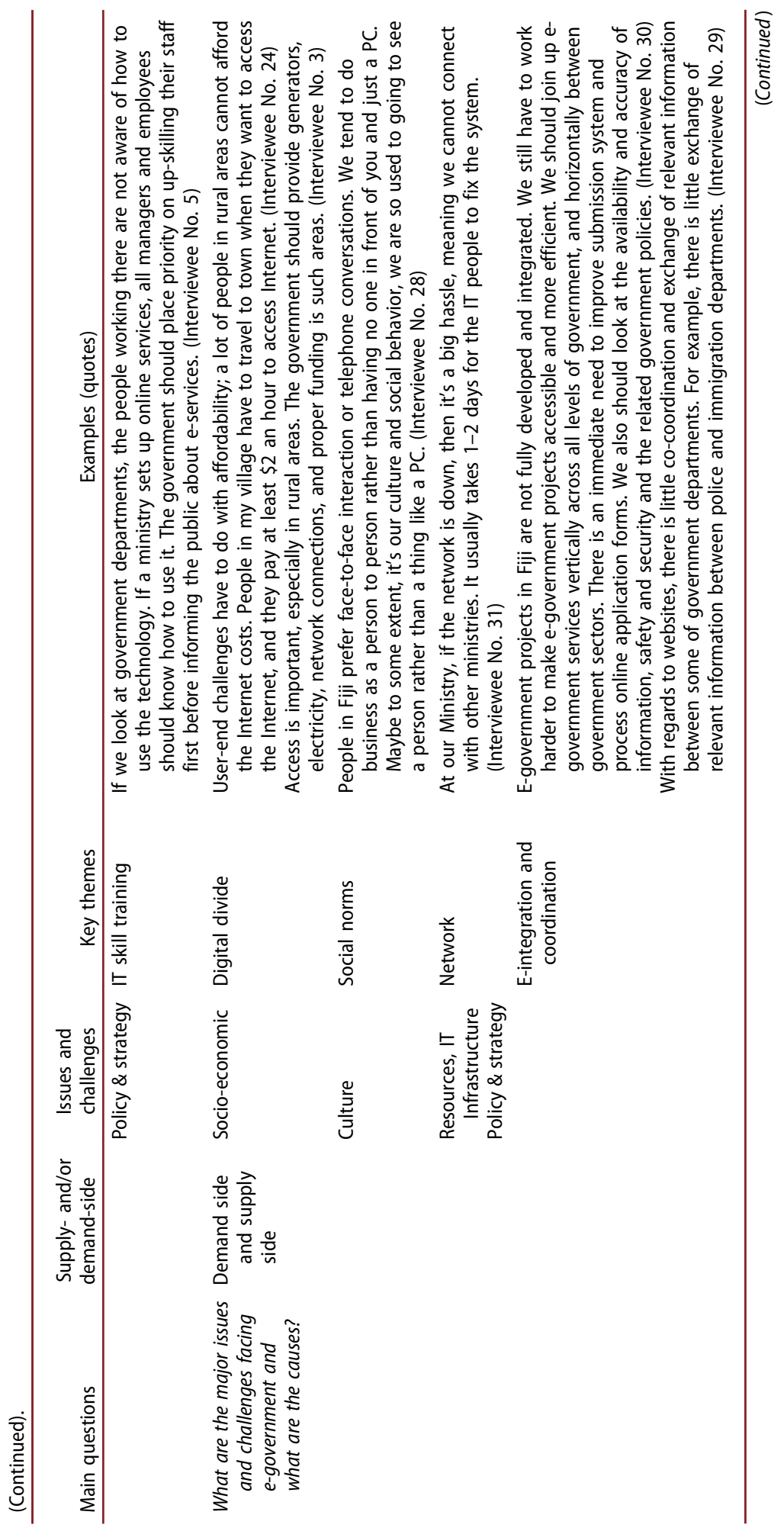




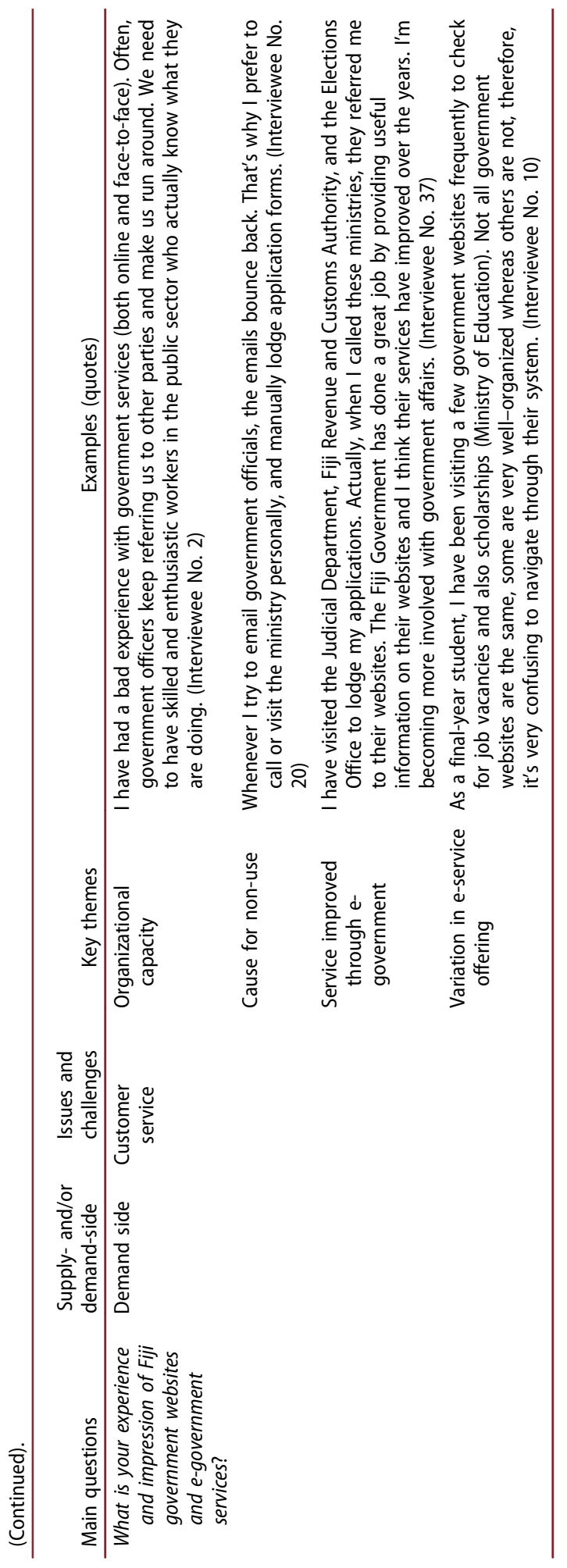

